\title{
Neurobrucellosis Accompanied by Sternoclavicular Arthritis: A Case Report
}

\section{Sternoklaviküler Artritin Eşlik Ettiği Nörobruselloz: Olgu Sunumu}

\author{
Hatice Köse, Fatih Temoçin, Serap Temoçin* \\ Yozgat City Hospital, Clinic of Infectious Diseases and Clinical Microbiology, Yozgat, Turkey \\ *Yozgat City Hospital, Clinic of Radiology, Yozgat, Turkey
}

\section{Abstract}

Brucellosis is a zoonotic infectious disease. It may show several manifestations and involve several systems, such as cardiovascular, hematopoietic, skeletal, nervous, and gastrointestinal systems and the skin. Sternoclavicular arthritis and prostatitis caused by brucellosis are rare conditions, which have been reported previously as case presentations in the literature. In this article, we present a case of neurobrucellosis accompanied by sternoclavicular arthritis and prostatitis to highlight that the disease may manifest with several signs and symptoms with rare involvements.

Keywords: Brucellosis, prostatitis, sternoclavicular arthritis, meningitis, vertigo
Bruselloz zoonotik bir enfeksiyon hastalığıdır. Genitoüriner komplikasyonlardan prostatit ve osteoartiküler tutulumdan sternoklaviküler artrit çok nadir görülür. Prostatit, sternoklaviküler artrit ve menenjit görülen hastamız brusellozun çok farklı semptom ve bulgularla ortaya çıkabileceğini hatırlatmak ve nadir tutulumlara dikkat çekmek amacıyla bildirilmiştir.

Anahtar Sözcükler: Bruselloz, prostatit, sternoklaviküler artrit, menenjit, vertigo

\section{Introduction}

Brucellosis, which is the most frequent zoonotic disease worldwide, is primarily a disease of animals such as sheep, goat, cattle and pig, and it is transmitted by contact with infected animals or their tissues, or by consumption of unpasteurized milk or dairy products (1). The risk of complications is less than $1 \%$ in early diagnosed and appropriately treated cases. Osteoarticular involvement, the most common complication, can develop in almost half of the patients. While sacroiliitis, spondylodiscitis, and peripheral arthritis are also common, sternoclavicular joint involvement is a rare entity (1-4). Genitourinary complications are reported at a rate of $5 \%$ to $10 \%$, and epididymoorchitis is the most common genitourinary complication. Prostatitis is another very rare complication, and a limited number of cases have been reported (1,57). Neurological involvement, which occurs in almost $10 \%$ of the patients, represents a serious complication. Neurological involvement is classified as acute meningitis or meningoencephalitis, chronic peripheral form (radiculoneuropathy), and chronic central nervous system infection (1). Herein, we present a case of brucellosis presenting with prostatitis, sternoclavicular arthritis, and meningitis, and we discuss the signs and symptoms and rare involvements in the light of the literature data.

\section{Case}

A 50-year-old male patient presented to our outpatient clinic with a swelling of the left side of his neck and left shoulder pain which increased by movement. His medical history did not reveal any chronic disorder and he worked
The manuscript was presented as a poster (PS0084) at 18 $8^{\text {th }}$ Klimik Congress in 2017

Address for Correspondence/Yazışma Adresi: Hatice Köse Yozgat City Hospital, Clinic of Infectious Diseases and Clinical Microbiology, Yozgat, Turkey E-mail: drhaticekose@hotmail.com ORCID ID: orcid.org/0000-0001-7806-7019

Received/Geliş Tarihi: 29 March 2017 Accepted/Kabul Tarihi: 30 June 2017
${ }^{10}$ Copyright 2017 by The Medical Bulletin of University of Health Sciences Haseki Training and Research Hospital
The Medical Bulletin of Haseki published by Galenos Yayinevi.

๑Telif Hakkı 2017 Sağlık Bilimleri Üniversitesi Haseki Eğitim ve Araştırma Hastanesi Haseki Tıp Bülteni, Galenos Yayınevi tarafindan basılmışıı. 
as a laboratory technician in microbiology laboratories and resided in the countryside. The patient was referred to the urology department with fever, widespread musclejoint pain, and urinary burning that started four months ago. He had prostate pain during physical examination. Laboratory investigations indicated that urine was positive for leukocytes and blood levels of total prostate specific antigen (PSA) was $42.57 \mathrm{ng} / \mathrm{mL}(\mathrm{N}: 0-3.87 \mathrm{ng} /$ $\mathrm{mL}$ ) and free PSA was $3.88 \mathrm{ng} / \mathrm{mL}(0-1 \mathrm{ng} / \mathrm{mL})$. With a preliminary diagnosis of prostatitis, he was initiated on oral ciprofloxacin $500 \mathrm{mg}$ bid for 14 days. Then, his fever and urinary system symptoms resolved, however, muscle-joint pain persisted. The patient started to have dizziness two weeks after completion of therapy, and he was referred to the department of ear, nose and throat department and neurology department. Hearing test and cranial computed tomography results were normal, and he was put on betahistine dihydrochloride therapy. However, he had persistent dizziness for the last three months despite therapy, and he had left shoulder pain for the last three days. His physical examination findings were as follows; body temperature: $36^{\circ} \mathrm{C}$, arterial blood pressure: $120 / 80$ $\mathrm{mmHg}$, conscious, cooperative, oriented, neck stiffness, Kernig's and Brudzinski signs negative. He had hyperemia, stiffness and temperature increase on left sternoclavicular joint, and left shoulder movements were painful. Other system examinations were normal. Laboratory findings were as follows; leukocytes: $8.1 \times 10^{3} / \mu \mathrm{L}\left(3.98-10.2 \times 10^{3} /\right.$ $\mu \mathrm{L})$ (58\% neutrophils, 32\% lymphocytes, $8 \%$ monocytes), hemoglobin: $13.9 \mathrm{~g} / \mathrm{dL}(12.2-16.2 \mathrm{~g} / \mathrm{dL})$, thrombocytes: $225 \times 10^{3} / \mu \mathrm{L}(142-424 \times 103 / \mu \mathrm{L}), \mathrm{C}$ reactive protein: 6.33 $\mathrm{mg} / \mathrm{L}$ (0-5 mg/L), erythrocyte sedimentation rate: $24 \mathrm{~mm} /$ hour. Since the patient had a history of fever and musclejoint pain and he was a laboratory technician, brucella lam agglutination test was found to be positive; standard tube agglutination (STA) was 1/160, and Coombs agglutination was found to be positive in $1 / 1280$ titer. Other biochemical investigations were normal. The patient was hospitalized in the infectious diseases clinic. Samples were obtained for blood culture. A lumbar puncture was performed with the preliminary diagnosis of neurobrucellosis. Non-stained microscopic examination of the cerebrospinal fluid (CSF) showed 120 lymphocytes $/ \mathrm{mm}^{3}$. In addition, CSF-gram and methylene blue staining did not indicate microorganisms. Biochemical CSF results were as follows; glucose: $44 \mathrm{mg} /$ $\mathrm{dL}$ (concurrent blood glucose: $90 \mathrm{mg} / \mathrm{dL}$ ), and protein: 60 $\mathrm{mg} / \mathrm{dL}(15-45 \mathrm{mg} / \mathrm{dL}$ ). Lam agglutination test was negative, STA was $1 / 16$, and Coombs agglutination was found to be positive in $1 / 32$ titers. The patient was put on intravenous ceftriaxone $2 \mathrm{~g}$ bid, oral rifampicin $600 \mathrm{mg}$ once daily, and oral doxycycline $100 \mathrm{mg}$ bid. The surface ultrasound sonography test of the sternoclavicular joint region showed a soft tissue edema (Figure 1). Vertigo started to regress as of the first week of therapy and completely disappeared by the second week. Lumbar puncture was repeated on the second week of therapy to evaluate the patient's response to treatment. The CSF biochemistry results were as follows; glucose: $50 \mathrm{mg} / \mathrm{dL}$ (concurrent blood glucose: $80 \mathrm{mg} / \mathrm{dL}$ ), protein: $50 \mathrm{mg} / \mathrm{dL}$ (15-45 $\mathrm{mg} / \mathrm{dL}$ ). Microscopic examination of the CSF indicated 30 lymphocytes $/ \mathrm{mm}^{3}$. Ceftriaxone therapy was stopped after being completed to four weeks. Oral trimetoprim/ sulfametoxazol (TMP-SXT) at a dose of 800/160 bid was added to doxycycline and rifampicin therapy. The clinical presentation of sternoclavicular arthritis completely disappeared by the second month of therapy. Lumber puncture was repeated at the fourth month of therapy, and no cell was seen in the microscopic examination of CSF. Biochemical parameters of the CSF were found to be within the normal limits. Blood STA had decreased to 1/40 titers. Rifampicin, doxycycline, and TMP-SXT therapy was completed at six months. The patient is still being followed without any complaint.

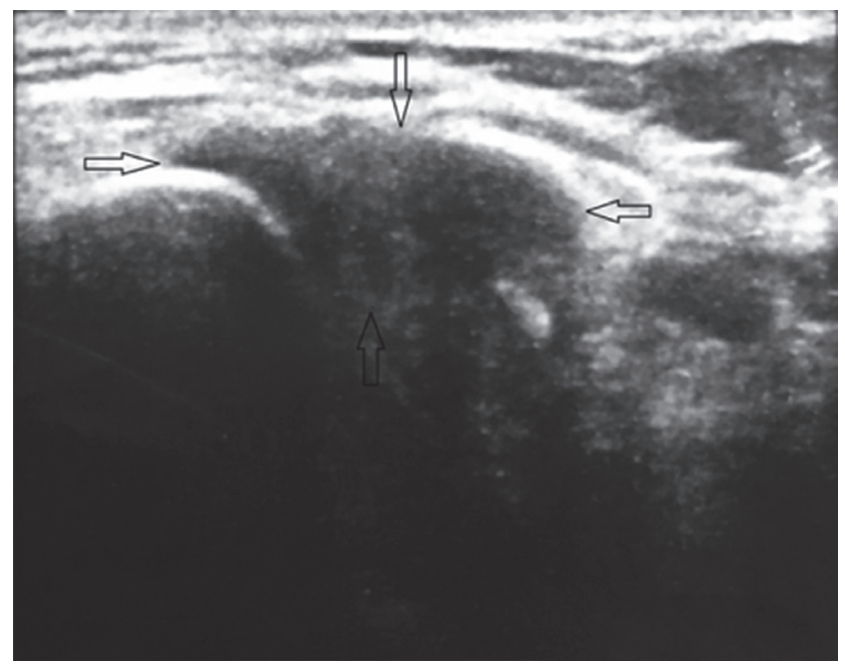

Figure 1. The surface ultrasound sonography test of the sternoclavicular joint region showed a soft tissue edema

\section{Discussion}

Brucellosis is the most frequent zoonotic disease worldwide (1) and endemic entity in Turkey, and its seroprevalence has been reported to be $1.8 \%$ in healthy population and $6 \%$ in the population under risk (8). During acute phase of the disease, patients frequently present with fever, fatigue, headache, back pain, loss of appetite, myalgia, and arthralgia (8). Our case had symptoms including fever, widespread muscle and joint pain, and dysuria at the disease onset. Ciprofloxacin was initiated with the diagnosis of prostatitis and his symptoms resolved 
after two weeks of therapy. Genitourinary complications have been reported in $5 \%$ to $10 \%$ of brucellosis cases, and the most common one is epididymoorchitis (1). On the other hand, prostatitis is very rare, and only a few case reports have been published to date, although the condition can be confused with a prostate carcinoma (5-7). We could not prove that prostatitis was due to brusellosis because of no blood culture positivity and isolation from the prostate tissue. Since at that stage brucellosis was not considered as a differential diagnosis, our case was not given appropriate therapy, and he stopped ciprofloxacin therapy after two weeks as the symptoms were suppressed. After two weeks without using antibiotics, the patient developed dizziness, headache, and neck pain and he was referred to physicians of different specialties over a period of three months. He was eventually referred to the department of infectious diseases, as he had pain and tenderness on the sternoclavicular region.

Osteoarticular involvement is the most common complication of brucellosis and can be observed in almost half of the cases. The most commonly seen forms are sacroiliitis, spondylodiscitis and peripheral arthritis (1). Sternoclavicular joint involvement, on the other hand, is very rare (0.7-2\%) (2-4). Neurological involvement may also occur in almost $10 \%$ of patients. While more than half of the patients with neurological involvement experience headache and fever, only one third of these patients show findings of meningeal irritation. Therefore, it may take years to diagnose the disease and it was previously reported that almost half of these patients apply to hospital with severe neurological sequelae (1). In the patient described here, headache and vertigo alerted us to consider neurobrucellosis, and upon appropriate therapy, the patient recovered without any sequelae.

Nonspecific symptoms of brucellosis may result in difficulties and a delayed diagnosis. In the presence of rare involvements such as prostatitis and sternoclavicular arthritis, brucellosis should be always kept in mind and vertigo, another rare symptom, can be suggestive of neurobrucellosis.

\section{Ethics}

Informed Consent: Informed consent was obtained from the patient for publishing the individual medical records.

Peer-review: Externally and internally peer-reviewed.

\section{Authorship Contributions}

Surgical and Medical Practices: H.K., F.T. Concept: H.K., Design: H.K., F.T., S.T. Data Collection or Processing: H.K., F.T., S.T. Analysis or Interpretation: H.K., F.T. Literature Search: H.K., F.T., S.T. Writing: H.K., F.T.

Conflict of Interest: No conflict of interest was declared by the authors.

Financial Disclosure: The authors declared that this study received no financial support.

\section{References}

1. Gül HC, Erdem H. Brucellosis (Brucella species). In: Mandell GL, Bennet JE, Dolin R, editors. Mandell, Douglas and Bennett's Principles and Practice of Infectious Disease. 8th ed. Churchill Livingstone: Philadelphia: 2015. p. 2584-89.

2. Andriopoulos P, Tsironi M, Deftereos S, Aessopos A, Assimakopoulos G. Acute brucellosis: presentation, diagnosis and treatment of 144 cases. Int J Infect Dis 2007;11:52-7.

3. Mousa AR, Muhtaseb SA, Almudallal DS, Khodeir SM, Marafie AA. Osteoarticular complications of brucellosis: a study of 169 cases. Rev Infect Dis 1987;9:531-43.

4. Colmenero JD, Reguera JM, Fernandez-Nebro A, CabreroFranquela F. Osteoarticular complications of brucellosis. Ann Rheum Dis 1991;50:23-6.

5. Hakko E, Oldsmar M, Turkoglu S, Calangu S. Acute prostatitis as an uncommon presentation of brucellosis. BMJ Case Rep 2009:2009.

6. Rosales Leal JL, Tallada Buñuel M, Espejo Maldonado E, et al. Acute prostatitis as the 1st symptom of brucellosis. Arch Esp Urol 2003;56:527-9.

7. Aksoy F, Aksoy HZ, Sözen EE, Yilmaz G, Köksal I. A case of Brucella prostatitis misdiagnosed as prostate carcinoma. Mikrobiyol Bul 2009;43:493-7.

8. Doganay M, Aygen B. Human brucellosis: an overview. Int J Infect Dis 2003;7:173-82. 